\title{
Design of Innovation and Entrepreneurship Education system in Application-oriented Universities
}

\author{
Long Chen ${ }^{1, a}$ and Pengzhong Dong ${ }^{2, b}$ \\ 'Jilin Teachers'Institute of Engineering and Technology, Changchun,Jilin , China \\ 2Jilin Teachers'Institute of Engineering and Technology, Changchun,Jilin , China \\ a414388426@qq.com,bsf_7988@163.com
}

\begin{abstract}
Keywords: Entrepreneurship education system; University innovation; Education system orientation; Education system frame design.
\end{abstract}

\begin{abstract}
The educational system is charged with the arduous task of improving the quality of the nation and cultivating the driving force for economic development, the enhancement of the comprehensive national strength, and social progress. Therefore, we need to combine the resources and own conditions of our research universities to analyze the demand of employment and market segmentation. And follow with the traditional education system, innovation and practice of the combination of the main body and interactive combination of the principles of innovation and entrepreneurship education system ideas and framework model to carry out a reasonable positioning and design.
\end{abstract}

\section{Foreword}

The education of innovation and entrepreneurship in application-oriented universities is a complex and systematic project involving the whole society[1].The concept of entrepreneurship will be integrated into the entire talent training system, and the sense of innovation and entrepreneurship will be integrated into the university education of college students in order to learn knowledge and acquire behavioral characteristics, and all students will be systematically trained and educated; We should integrate the idea of innovation and entrepreneurship into the university curriculum, standardize it in the curriculum, cultivate the core qualities necessary for college students to join in and start their own businesses, break through the limitations of classroom teaching, and increase practical educational courses and scientific and technological activities. In the practice teaching, we should cultivate the students' creative ability, stimulate their interest in study and promote the change of the teaching mode, the teaching attitude and the teaching method, through the classroom teaching, the practice competition, the pioneering base, the campus culture and so on many kinds of forms of education and the exchange. Make necessary preparations for them to choose to start a business[2,3].

\section{The Framework Model and Module Analysis of Innovation and Entrepreneurship Education system in Application-oriented Universities}

In order to promote the scientific, standardized and systematic implementation and research of innovation and entrepreneurship education, it is necessary to construct a complete system and model for the implementation of innovation and entrepreneurship education in application-oriented universities[4,5].

This paper explores the operational management mode and implementation mechanism of innovative entrepreneurship education in application-oriented universities, that is, innovating the traditional teaching and training model, and permeating innovation and entrepreneurship into every link of the educational process from the aspects of educational process, methods and methods. At the same time, we develop various mechanisms that can effectively promote the development and upgrading of the system. This chapter mainly focuses on the research on the internal system module 
and operation mode of developing innovation and entrepreneurship education in research universities.

The objective and idea system of Innovation and Entrepreneurship Education in Application-oriented Universities. We should pay attention to the following aspects to orientate the education of innovation and entrepreneurship rationally: first, the education of innovation and entrepreneurship in application-oriented universities should face all the students and be carried out throughout the course. From the first year of college students should begin to pay attention to the cultivation of entrepreneurship and entrepreneurial ability, and with the increase in grade students to increase the intensity of this kind of education. Second, the education of innovation and entrepreneurship should pay attention to individual and professional differences[6,7].Colleges and universities should set higher goals and requirements for students who have the will and conditions to start a business. Third, the education of innovation and entrepreneurship should conform to the characteristics of the era of knowledge economy and be oriented by scientific and technological entrepreneurship.

In addition, college students should change their concept of employment and start their own business as a new way out. At the same time, the whole process of the education system of innovation and entrepreneurship should revolve around the cultivation of students' innovative spirit and innovative ability. Cultivate broad vision, sharp reaction, strong dedication, strong willpower, rich organizational and management skills, the courage to practice challenges, energetic talent.

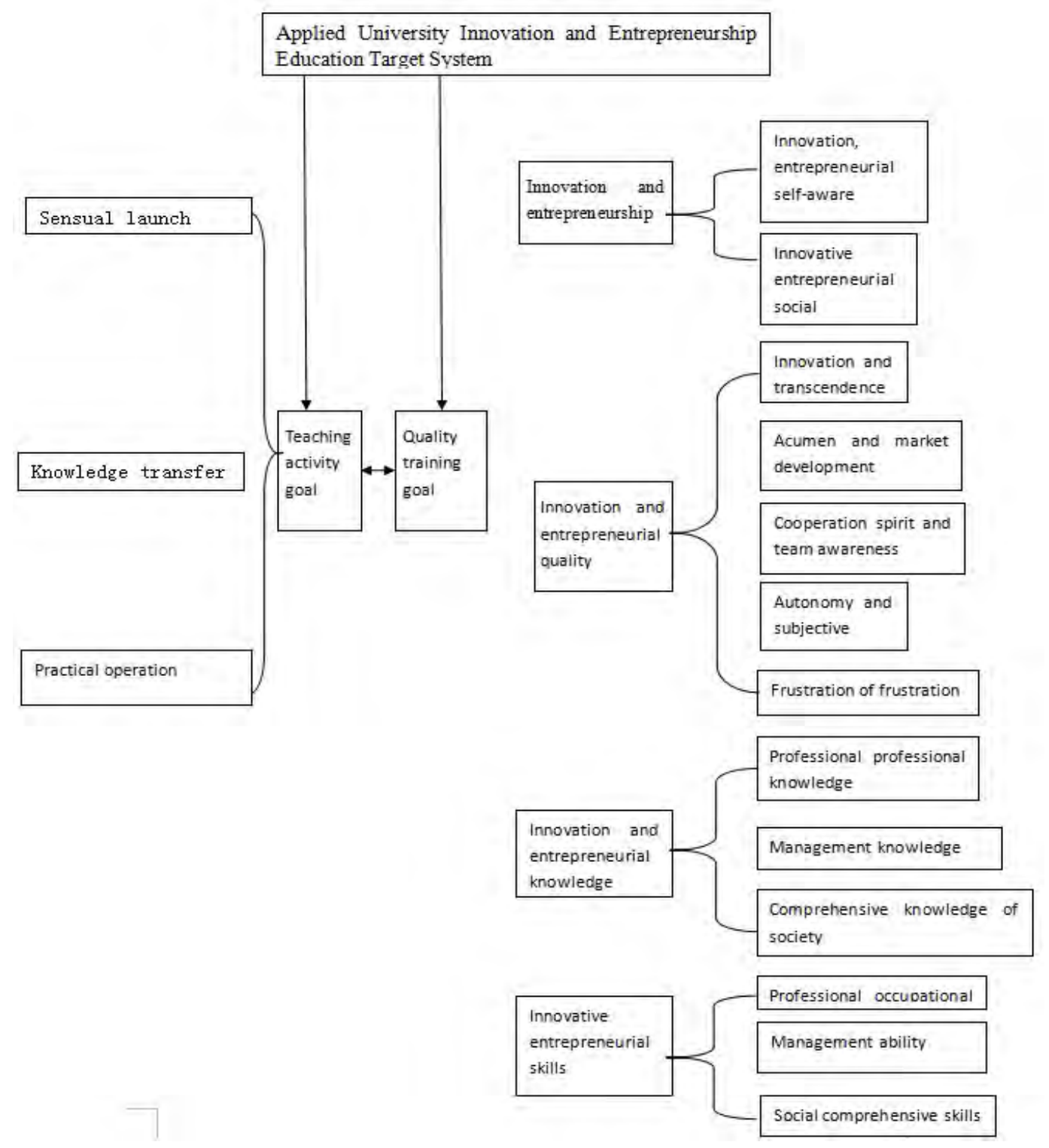

Figure 1.objective system of innovation and entrepreneurship education in application-oriented universities 
Organizational Environment system of Innovation and Entrepreneurship Education in Application-oriented Universities.The organizational environment system here mainly refers to the internal environment of the application-oriented university, which embodies the organizational support and resource input for innovation and entrepreneurship education provided by the application-oriented university. It mainly includes two aspects: hard environment and soft environment. The former refers to the various safeguard measures of the school in the material aspects such as innovative and entrepreneurial funds, infrastructure and so on. For example, through the establishment of entrepreneurship centers, the latter refers to the academic, atmosphere and culture in which schools encourage innovation, entrepreneurship and tolerance of failure, and stimulate students' spirit and enthusiasm for innovation and entrepreneurship through relevant policies, systems and measures. It provides the inner material guarantee for the education of innovation and entrepreneurship. Hard environments require more physical input from schools and are easier to build. Soft environment is to strengthen management and education, the school needs to lead the creation of all its teachers and students. This is more important for the implementation of innovation and entrepreneurship education[8].

The participant system of Innovation and Entrepreneurship Education in Application-oriented Universities.

In the research on the influencing factors in the early stage of this project, the participants in the education of innovation and entrepreneurship have been introduced. This paper mainly analyzes the internal participants of the innovative and entrepreneurial education system of applied universities: management team, faculty and student groups.

Curriculum content system of Innovation and Entrepreneurship Education in Application-oriented Universities.Curriculum content and subject construction, namely the design and arrangement of the related theories and practical courses such as entrepreneurial consciousness, knowledge, strategy, ability, quality, etc. The scientific and reasonable curriculum content system should be constructed according to the goal system of innovative entrepreneurship education[9].

Focus on the construction of the whole, and the overall consideration of the part, so that students really in the "wide professional, thick foundation, emphasis on practice" curriculum system in the development. According to the different nature of the major, the selection of different emphasis, such as engineering, art and other related majors can strengthen innovative education, cultivate innovative results, promote the transformation of results, and encourage students to use the concept of innovation.

Practical platform system of Innovation and Entrepreneurship Education in Application-oriented Universities.College education should not only educate the students in theory, but also cultivate their practical ability and strengthen their practical skills and training, which is also in line with the educational requirements of innovative and practical activities. In this regard, the school must establish a complete set of "industry, university, research" joint education system, will be able to be used within the scope of the practice of teaching the full use of the base, the establishment of colleges or the construction of disciplines.

\section{The running Mode of "three classrooms" in the Education system of Innovation and Entrepreneurship in Application-oriented Universities}

The change from attaching importance to imparting theoretical knowledge to attaching importance to quality cultivation and skill development will give students the opportunity to discover problems and guide them to acquire new knowledge with their own thinking;The combination of theory and practice, and the combination of on-campus and off-campus learning is to strengthen the practical ability of students' employment and entrepreneurship. Teaching students new theory, new knowledge, new technology, new means, more emphasis on the cultivation of development stamina, highlight the development of creativity, cultivate innovative thinking. According to this idea, this project designs the "three-classroom model" of the operation of innovative entrepreneurship education, as shown in Fig. 2: 


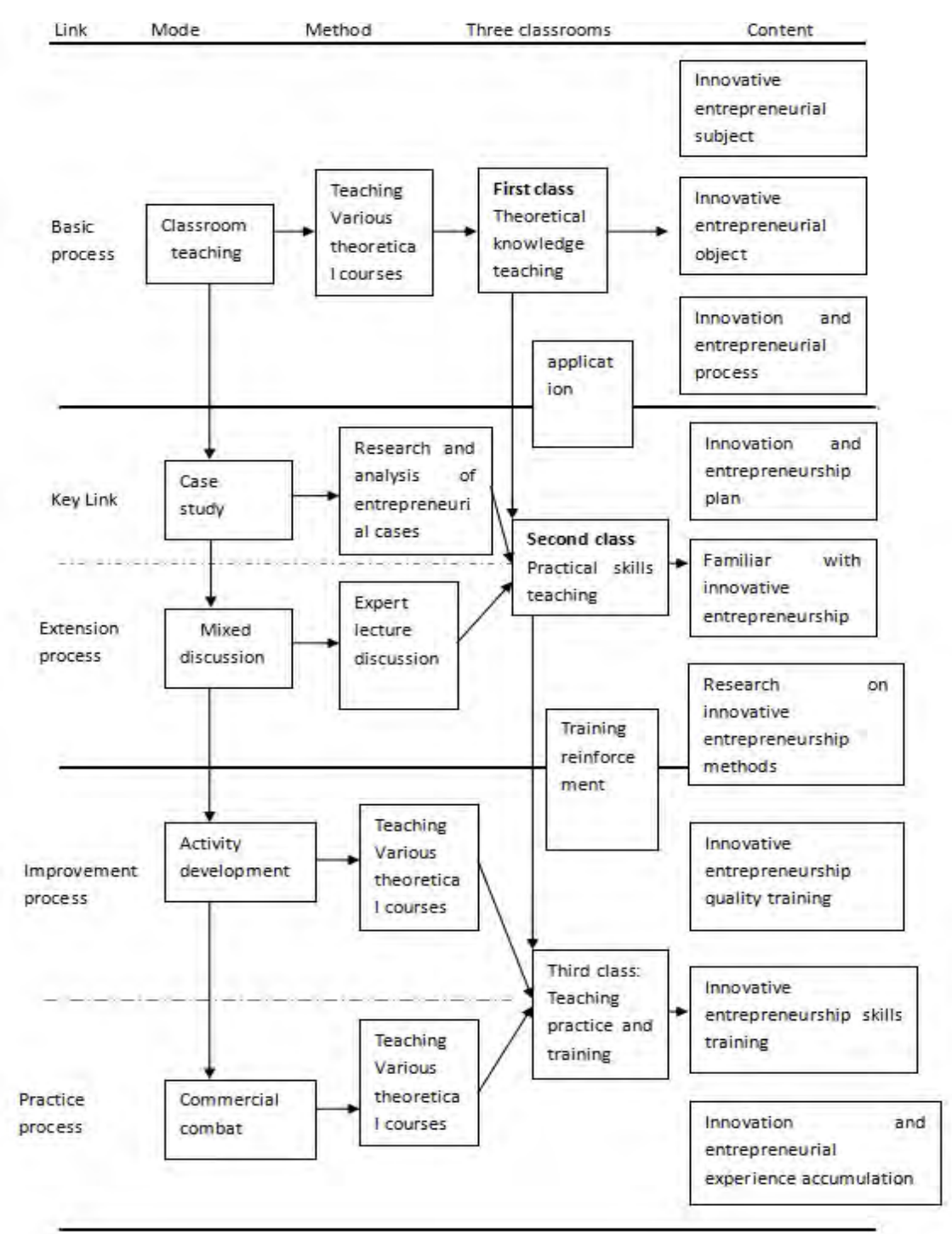

Figure 2. "Three-classroom" operation mode of innovative and entrepreneurial education in application-oriented universities

\section{Conclusion}

The theoretical knowledge teaching, practical skills teaching and practical training teaching in the teaching process of innovation and entrepreneurship education in application-oriented universities are defined as the 1st, 2nd and 3rd class respectively.

Among them, the first classroom education into the professional training plan, and the completion of the syllabus within the time the classroom teaching content; and the second, third classroom education should be targeted at individual students to set educational objectives in advance; It is all the practical activities related to innovation and entrepreneurship education outside the planned class hours. It is missing from the traditional education system and is relatively difficult to implement. Its realization needs to make full use of the practice platform system as a carrier and support.

\section{Acknowledgements}

Jilin provincial department of education social science project 2017.Project name: Study on education system for innovation and entrepreneurship in application-oriented universities (special employment project). Project number: JJKH2017184SK 


\section{Reference}

[1] Semra Guven. World Conference on Edueational Seiences 2009[J].New primary edueation course programmes and entrepreneurship[J].Proeedia Social and Behaviora Seiences 2009(1):265.

[2] Shane B , Venkataraman S. The Promise of Entrepreneurship as a Field of Research. Academy of Management Review, 2000,25:217-226.

[3] Robert M. Henry, Susan M. Richey. Interdisciplinary Experiential Education of Intellectual Property Concepts in an Engineering[J].IEEE, 2010.

[4] Jerome A Katz.The chronology and intellectual trajectory of American entrepreneurship education[J] . Journal of Business Venturing . 2002 (2).

[5] Thomas N. Garavan,Barra O'Cinneide.Entrepreneurship Education and Training Programmes: A Review andEvaluation - Part 1[J] Journal of European Industrial Training . 1994 (8).

[6] Allan Gibb.Concepts into practice: meeting the challenge of development of entrepreneurship educators around an innovative paradigm:The case of the International Entrepreneurship Educators' Programme (IEEP)[J] .International Journal of Entrepreneurial Behaviour \& Research. 2011 (2).

[7] Harry Matlay,Charlotte Carey.Entrepreneurship education in the UK:a longitudinal perspective[J].Journal of Small Business and Enterprise Development. 2007 (2).

[8] Harry Matlay. Entrepreneurship education in UK business schools:: Conceptual, contextual and policy considerations[J]Journal of Small Business and Enterprise Development . 2005 (4).

[9] CandidaG. Brush. Doctoral Education in the Field of Entrepreneurship[J].Journal of Management . 2003 (3). 